\author{
KAZIMIERZ MISIASZEK SDB* \\ Warsaw, Poland
}

ORCID ID oooo-0002-3606-9523

\title{
CATECHESIS AND EDUCATION AS A FUNCTION OF BUILDING THE CHURCH ACCORDING TO FR. FRANCISZEK BLACHNICKI (ON THE CENTENARY OF THE BIRTH OF THE GREAT EDUCATOR)
}

\begin{abstract}
For Fr. Franciszek Blachnicki, the catechesis was in close relationship with the Church. The most appropriate place for the catechesis as the fundamental formation of Christians (adults, youth and children) is in the Church which is both the subject, goal and object of catechesis. Fr. Franciszek Blachnicki drew the concepts of the Church from studies by German-speaking authors, and above all from documents of the Second Vatican Council. For him, the Church was an intermediary of salvation, a universal sacrament of salvation, a mother, a temple of God, and most of all, a union of God's people, a community in Christ, a community of faith, hope and love. The task of catechesis is, in the first place, the introduction and experience of the Church. The nature of catechesis stems from the concept of the Church. Therefore, if the Church is a community, the aim of catechesis is to introduce it to the faithful so that they may not only participate in it, but above all create it. It is also important that catechesis serves the process of Christian initiation, discovering the Church as a place of fulfilling the mystery of life, salvation and healing. Therefore, Fr. Blachnicki put a strong emphasis on the relationship between the liturgy and catechesis, because the most complete process of initiation takes place in the liturgy. Another task of catechesis is its function of awakening and developing faith. For faith is the foundation for the Church and the primary goal for catechesis. It is to be both personalistic and social in nature. Father Blachnicki claimed that cathechesis educated faith was not an individual faith but the faith of the Church. Many Christians, even including those most zealous, live their Christian lives alongside the life of the Church, but not in the Church. In the meantime, every Christian is the Church, because the Church is the whole Christ, the head and members, and we are its members. For that reason, the life of the Church grows in so far as the life of faith of each member grows.
\end{abstract}

Keywords: Fr. Franciszek Blachnicki, the concept of the Church, catechesis, life and experience of the Church, faith and catechesis, education.

* Prof. dr. hab. Kazimierz Misiaszek, Salesian, Cardinal Stefan Wyszyński University in Warsaw, Faculty of Theology, Head of the Department of Practical Theology; e-mail: k.misiaszek@uksw. edu.pl. 


\section{Father Franciszek Blachnicki's understanding of the Church}

The reflection of Fr. Franciszek Blachnicki on the essence of the Church indicates that, although he largely drew on the basic content of the documents of the Second Vatican Council, he also presented a rather extensive state of discussion in his papers preceding the Council's view of the Church and, above all, pastoral theology. One must know that Fr. Franciszek Blachnicki did not write directly about the Church, but was mostly interested in the search for the essence of pastoral theology integral to the Church. But we can find in his studies a certain understanding of the Church. He appealed primarily to the then recognized authorities in pastoral theology and ecclesiology, mainly in the German speaking world. It can be seen that the achievements of German-speaking pastoral theology became his thought, integrally linked also to his own attempts to understand pastoral theology and the Church.

Blachnicki recognized the thoughts of Antoni Graf (1811-1867) as a kind of true Copernican upheaving in pastoral theology. As he wrote, "Antoni Graf owes pastoral theology primarily to the idea of the fundamental importance of the methodology of this discipline, namely that the determination of its essence, purpose and division must be sought in essence by the Church united with Christ, its Head. In constructing this teaching (...) it is necessary to take into account both the experience and theological principle brought out of the essence of the Church, and they must remain final and decisive. Graf, therefore, consciously attempts to deduct the concept of pastoral theology from the idea of the Church" (Blachnicki 2015, p. 59) From Graf's concept, Fr. Blachnicki brought out such terms of the Church as the church's continuous presence by the Holy Spirit of God's salvific works, the living continuance and making God's salvific work continuously present, „which acted not only at the beginning, assuming it, but works continually throughout history in Him" (Blachnicki 2015, p. 61). We therefore have both The Christological, Pneumatological and soteriological aspects in determining the Church, which will appear in the further definition of the Church by Blachnicki.

In Fr. Blachnicki's research we will find the fundamental concept of Francis Xavier Arnold (1898-1969), which he considered extremely important for his further research. In his general pastoral theology, there is a justification for Arnold's contribution: „Arnold's historical and pastoral studies make one important and fundamental demand for pastoral theology: It must derive principles from the church's knowledge in the light of Revelation for its pastoral activity" (Blachnicki 2015, p. 34; Marczewski 2000, pp. 120-123. The Church is therefore the source of the pastoral action of the community of God's people and, above all, a tool of salvific mediation, standing in the service of this process. The way in which the Church is understood influences the nature of its pastoral activity in a decisive way, and it is, above all, captured in the light of the mystery of Revelation, being a divine-human reality, which was important for Fr. F. Blachnicki in order to 
deepen his view, as well as to move decisively away from the reductive, mainly anthropocentric concepts of pastoral theology. Emphasizing the importance of Arnold's divine-human principle, he first of all drew attention to the essence of the Church's salvific mediation, which must be properly understood. He wrote: "Mediation must be understood and exercised in such a way that it reveals God as subiectum principale [essential subject]. God must, as it were, shine through the activities, the acts of human mediation in the Church; it must be somehow visible and knowable that God is behind them and that the mediation [of the Church] is an instrumental activity" (Blachnicki 2015, p. 80) The Church is therefore understood as a ministerial tool in the process of salvific mediation, and this thought will crop up through in many further analyses undertaken by Blachnicki. On the other hand, the necessary completion of the image of the Church as the mediator of salvation is to take into account Christ as the only Mediator, and thus to take into account the Christological dimension, crucial for the understanding of the Church.

From the theological and pastoral work of Karol Delahaye (Delahaye 1958), a disciple of Arnold, Blachnicki took the image of the Church as the Mother (Ecclesia Mater), constantly giving birth to new members (mater semper in partu). It should be mentioned that the description of the Church as a mother is also found in the Dogmatic Constitution on the Church Lumen gentium (No. 6). The task of the Church is to be the mediator of salvation in the sense of giving birth, feeding and caring. "Serving in that way, the Mother Church transmits to humanity all that she has received through her union with Christ. She gives birth, feeds, and raises her children not for herself, but for the Kingdom of God" (Blachnicki 2015, p. 98). At the same time, this maternal task has a specific character, which is revealed in the truth that the formation of Christ in the faithful through the ministry of the Church is to be carried out in such a way that the children of the Church become the Church themselves, perfecting themselves and fulfilling its tasks (Blachnicki 2015, p. 99). This image will be enhanced in the pastoral studies of Fr. Blachnicki by combining the truth about motherhood with the truth about the Church, with the Church being understood as the Bride of Christ. And it is these two dimensions, according to Fr. Blachnicki, that reflect the deepest essence of the Church. And this thought of the Servant of God will also find its place in the teaching of John Paul II, for example, in his Mulieris dignitatem letter. By these means he draws a model from Mary, who is the prototype of the Church and of all union with God in Christ (1988).

From pastoral theology in the view of Karl Rahner and H. Schuster, Fr. Blachnicki came to the idea that in the meaning of the Church one must not be limited to one aspect, but must essentially take into account its total and dynamic essence. "The Church must be included as sacramental, historical and social greatness" (Blachnicki 2015, p. 123). It is, on the one hand, rooted in history as the presence and embodiment of God's salvific plan, on the other hand, „it presents personal devotion to God of a single man who can achieve it only as a lasting event in the Church and 
becoming a historical event in it" (Blachnicki 2015, p. 124). This description can be completed by another term, quoted by F. Blachnicki: The Church is „a socially constituted community in which the eschatologically completed Revelation of God (as his self-giving) through faith, hope and love remains present in Christ in the world as reality (Wirklichkeit) and truth (Wahrheit)" (Blachnicki 2015, p. 146). Rahner's statement can be deemed as important as it describes the Church as a community that realizes itself in all its dimensions, which Fr. Blachnicki defined as the realization of the Church (Marczewski 2000, p. 124).

Fr. Blachnicki found a clear understanding of the Church as a community in the work of the Viennese pastoralist Ferdinand Klostermann (1907-1982). This community has a lasting value, and at the same time is a mystery and entry into it takes place through personal acts "in which a man in faith and love responds to Christ's call. However, the personal acts that constitute the encounter with Christ can take place in the maternal womb of the Christian community, in which the Lord's Word resonates and participates in the Body and Blood of the Lord. Furthermore, through personal acts of faith and love, the Church is always built as a community, as the home and temple of God. The Church is built by all the deeds of the faithful in a state of grace. The Church cannot therefore be understood as a loose union of individuals, each of whom seeks only their own individual salvation, but is the community through which everyone receives salvation" (Blachnicki 2015, p. 171).

The confirmation of the Church's understanding of the community took place during the Second Vatican Council. Fascinated by the ecclesiology of the Council, Blachnicki sought both principles for his pastoral theology, also gave a broader understanding of the Church as a community (Szymczak 2018; Czaja 2004). He made it clear that "the view of the Church as a community in Christ is the leading thought of the ecclesiology of Vaticanum II" (Blachnicki 2013, p. 194), in which the idea of community in Christ is clearly sounded and is a guiding principle pervading everything, and the very truth about community is an effective sign of the Church, which is particularly evident in the Constitution on the Holy Liturgy and the Dogmatic Constitution on the Church. The Church, however, is a community not so much in a sociological sense, but as a theological one, and therefore as a community it is the mystery of unity, the gathering of people into one in the implementation of the Father's plans, in union with Christ, in the love of the Holy Spirit. It is therefore the people unified by the unity of the Father, the Son and the Holy Spirit. Moreover, it is "a community of faith, hope and love, a visible organism and a mystical body of Christ, (...) spiritual community" (Blachnicki 2013, p. 197; Marczewski 2000, pp. 195-238). And in this sense, the concept of community in Christ is closest to the purposes of the life and action of the Church.

According to Fr. Blachnicki, the combination of the concept of the Church as a community and its understanding as the universal sacrament of salvation (by Y. Congar) „unexpectedly reveals the closest and mutual relationship of the two. It turns out that the concept [an idea] of community explains only the proper content 
of the Church's view of the sacrament, and on the other hand, the concept of the sacrament determines in what sense the Church is a community. Although council documents do not explicitly link the concept of the sacrament to the concept of community, they do use equivalent terms. It is the name unity or unification. (...) it is always about uniting people with God and with each other in Christ, and this unity coincides with the content of the term koinonia [community] (Blachnicki 2013, p. 232). In this context, it is suggested that the Church should also be called the sacrament of the community, in which a man enters into a relationship with God and at the same time deepens his relationship with others (Marczewski 2004). Behind the Dogmatic Constitution on the Church, he argued that this mystery of unity is based on the Holy Trinity, hence the deepest mystery of the Church's unity and community (Blachnicki 2013, pp. 231-233, 247).

Deepening the theme of unity and community, Fr. Blachnicki also referred to other statements of the Council, repeating after the Dogmatic Constitution on the Church (No. 8) that it is also a community of faith, hope and love, as well as (after the Decree on Ecumenism, No. 2) that it is the unity of faith, hope and love. He reasoned that „Council documents very often point to theological virtues as a proper bond that determines our unity with Christ in the Church. They update our personal reference to God. Faith plays a special role here. Faith, understood as a personal relationship to Christ present in his Word foretold in the Church, is the foundation of the Church, through it enters man into his community, because God, the Eternal Father of „believers [...] in Christ decided to gather in the Holy Church" (Blachnicki 2013, p. 255; Marczewski 2018, pp. 274-275).

The Church, understood in this manner, is also a fraternal community, which for Fr. Blachnicki is a fact that flows from both the natural conditions of social life and biblical truth and of theological reflection. In this regard, he referred, above all, to the statement in the Pastoral Constitution about the Church: „God, who cares for everything, wants all people to form one family and to refer to one another in a spirit of fraternity" (No. 24). He emphasized that the source of this fraternity is Christ, who by incarnation became a brother to people and at the same time the foundation of a new fraternity between them. Justifying further, he wrote that „in the notion of fraternity and fraternal community (...). The emphasis rests on the relationship of individuals and personal groups to the community, so it is about a specific, living relationship between person and person, that is, fraternal love" (Blachnicki 2015, p. 285).

\section{Catechesis as the implementation and experience of the Church}

Regarding the determination of catechesis's relationship with the Church, Father Franciszek Blachnicki made it clear that it was connected with the Church from the very beginning, taking into account its nature and purpose and the nature of the Church's mission. He placed it in the broadly understood pastoral (practical) 
theology as an integral part of it. As in determining the essence of pastoral theology, he saw the need to extract its nature and purpose from the essence of the Church. For him, catechesis should always be seen in ecclesial terms. It is his understanding of the nature of catechesis that finds its lasting place today in both the Church's teaching (Jan Paweł II 1979), theology and the ecclesiology of catechesis, when it is clearly obvious that the Church creates catechesis and catechesis builds up the Church (Alberich 2003, pp. 182-193). The Directorium on catechesis also includes catechesis in ecclesial terms (2020).

Fr. Blachnicki saw the more precise definition of the ecclesial nature and purpose of catechesis ,in modern pastoral theology, which, among the basic functions through which the Church is realized, also enumerates the catechetical prophecy of the word of God" (Blachnicki 2006, p. 167; Misiaszek 2018). He associated this function primarily with the catechumenate, claiming that it was based on Christ's command to "teach all nations” (Mt 28,19). The catechumenate, in a broadly understood sense, was an institution to which catechumen were scheduled to be accepted and methodically cared for. He made it clear that catechumenate should be understood as ,a form of care given by the Church to all who are not yet mature in the faith. (...) As a dynamic reality, the Church, as the people of God and the mother of believers, must always look to the future, care for the generations growing up and prepare them for the Lord. In order to accomplish this task, the Church must be fully present in its time and must find a form of catechumenate which is adapted to the requirements of the hour of salvation - kairos" (Blachnicki 2006, p. 169).

Another justification for the ecclesial nature of catechesis, which seems particularly close to Fr. Blachnicki, was the opinion of the French catechist André Liégé, who placed catechesis within the tradition of the Church. As Blachnicki reported, he understood this tradition in his own way: „it is equated with the Church, which is a living Tradition, which is a permanent word of God in history. The Word of God from revelation becomes a living tradition in the Church. One form of this tradition is catechesis. Catechesis is therefore an act of the Church. The Church has been involved in it since the beginning. It follows that the catechist must also be deeply in the Church with his faith and existence" (Blachnicki 2006, p. 170).

The justifications given by Fr. Blachnicki for the ecclesiastical nature of catechesis do not exhaust the relationship of catechesis with the Church. It was obvious to him that catechesis must have an integral connection with the liturgy. Indeed, if the catechumenate implements the community of the Church, in which the catechumen is later to be baptized to be united with Christ and to be entrenched in his Paschal mystery through the sacrament of Baptism and the Eucharist, then the Church must be revealed as a liturgical, Eucharistic community. This community took catechumen into themselves, awakening faith in it and sustaining it. From this fact it was logical for the Servant of God that catechesis becomes, as he claimed, "a mystagogia, a leader towards Christian initiation and Christian initiation in 
the mystery of Christ and his Church, the inclusion in the community of believers and the praying Christians gathered around the altar" (Blachnicki 2005, p. 131).

Besides justifying the ecclesial nature of catechesis, Fr. Blachnicki also defined its closer objectives towards the Church in the Fundamental Catechesis. On the one hand, it is to be, as he called it, a supernatural social education, on the other, to properly state the content about the Church. Father Blachnicki wanted to undertake religious social education in accepting the truth about the social nature of a man, his innate need for social life. Referring first to the contemporary achievements of pedagogy and to the opinion of Father Jack Woroniecki, he reasoned that this issue is becoming extremely important today, since modern Christian life, inherited from the 19th century, is threatened by "religious individualism, the making of religion a personal and private matter, which has been reflected especially in the disappearance of a sense of social responsibility for the Church and an understanding of the duty of apostolate. The danger of our time is the process of human dissemination, the loss of human personality in the mass" (Blachnicki 2006, pp. 205-206). For this reason, he proposed that, in the renewed theology and catechesis, in the spirit of the Tübingen School, as well as on the basis of the teachings of the Second Vatican Council and the new post-council catechisms, he should properly introduce to the teaching of the Kingdom of God and the Church, understood as the mystical Body of Christ, the truth of the social essence of supernatural education. He also wrote that it was not enough in religious education to lead to a personal experience of God's childhood in Christ, although he considered it a fundamental experience in the process of education in faith (Misiaszek 2018a), but „such a deep attitude of the young soul to the Saviour (...) to accommodate in the supernatural social framework which constitutes the Church-Mystical Body of Christ - and to bring it to this unity and supernatural solidarity, which ought to be an outstanding feature of the Christian character" (Blachnicki 2006, p. 209).

The catechesis on the Church, which is particularly sensitive to the dogmatic Constitution of the Second Vatican Council Lumen gentium, is intended to be, according to Fr. Blachnicki, a complete reflection of its contents. He therefore proposed, in catechesis, to move away from the catechism definitions of the Church and from The Scriptures to draw those shots and images (the people of God, the Kingdom of God, the Body of Christ, the bride of Christ, the blue Jerusalem, the vineyard, the flock, the building and the temple) which express the essence of the Community of the Church. The Church, he claimed, is to be shown in catechesis as the mystery of the saving presence of Christ and the Holy Spirit in the world. This will be achieved through a close connection between catechesis about the Church and catechesis about the sacraments and the liturgy in general. However, the sacraments must be presented not only as signs of revealing but, above all, as signs of the realization of the Church. 
Opposing the artificial sharing of the content of catechesis into separate thematic blocks, he argued that this way the catechized does not receive a holistic vision of Christianity integrating all other values, does not see the Kingdom of God present in the Church, but the sum of canons and interdicts, rites and dogmas. He therefore proposed to realize the principle of concentration in catechesis, especially through the postulate of Christocentrism as an idea that permeates and unites internally all catechesis, and is specifically realized in the extraction of not so much the historical Christ as Christ glorified in the liturgy. For him, this demand also coincided with the demand for ecclesiocentrism in catechesis, which allowed him to answer unambiguously the question of the Church's place in catechesis (Blachnicki 2006, pp. 210-211). He therefore suggested that the Church should not be placed in the catechetical programme in a number of catechetical units, „but that the whole catechetical programme should be regarded as a place where the Church must be present" (Blachnicki 2006, p. 211). It is essential that „the entire catechesis leads to the Church, so that the various topics or aspects of catechesis are like the streams falling into one sea" (Blachnicki 2006, p. 211).

For Fr. F. Blachnicki it was extremely important that catechesis leads to the discovery and survival of the Church, taking into account the diverse beneficiary, the periods of his development, environmental conditions. Moreover, if catechesis is to build up the Church by introducing new generations into it, it will do the most when it is seen and experienced as a real reality. Such catechesis should, however, be existential in nature and thus indicate the life values that are present in the Church. For the Church cannot be seen as a detached from life, an abstract idea, but as a reality that can be experienced, an experience that is within the reach of the experience of the catechized. Otherwise, it will lead into the unknown. It must therefore be experienced above all in a specific liturgical, Eucharistic gathering, for the Church is realized in the liturgy and (Kulbacki 2018, pp. 61-64), as he claimed, „in the ecclesiology of the Christian family”. And the latter indicated the place that was especially important to him. He claimed that „all the efforts of catechesis to build and renew the Church will then bear fruit when, in parallel with it, the hardship of the renewal of the Church in families and parishes gathered and built from the Eucharistic table is developed" (Blachnicki 2006, pp. 212-213).

\section{Catechesis in the Service of Faith for the Building of the Church}

Fr. Franciszek Blachnicki developed a complete, integral and coherent concept of catechesis, advocating its kerygmatic dimension. He was an opponent of catechesis, in which the anthropological element would prevail, because he clearly saw and documented that catechesis, through its excessive links with the science of man (psychology, pedagogy, didactics) it had lost its original character. It has become a religious lesson, which emphasizes mainly the intellectual and didactic aspect. Meanwhile, catechesis, he claimed, is to remain in the service of faith, to be brought 
up in faith, for it is this faith that is the primary aim of catechesis (Murawski 2011). This aim is also equated with the Church's goal, for which the faith of its members is also fundamental. Faith, as we have shown above, is the foundation of the Church's life and through it a man enters its community. This way, faith also performs its most fundamental function in catechesis, which is Christian initiation. As Fr. Wojsław Czupryński writes, it was the initiation of Fr. Blachnicki that he considered as an element constituting the identity of catechesis, because it introduces the catechized in religious experience as the irreplaceable foundation of every Christian formation (2011, p. 181). It would be desirable for this formation to take on a catechumenal character, which has become a fact in the Light-Life Movement founded by him (Blachnicki 2003).

For Blachnicki this emphasis on the primary role of faith was not only to reveal an objective truth about the purpose of catechesis, but it also stemmed from the modern pastoral situation, which records the crisis of faith of a modern man, the increasing secularization of life, scepticism and nihilism (Blachnicki 2005, p. 95). It can also be added that, in the current situation, there are still changes in this area, which are commonly referred to as the privatisation of the faith, that is to say, treating it as a private matter, reserved only for private life, with the exclusion of its connection with social life. Hence, father Blachnicki's correct and timely observation that faith when it is reduced to the order of immanent, humanistic values loses its supernatural power, it does not convert a man, does not engage him personally and does not give strength to solve life's problems. Also valid is his call to preach today a faith that will again call man through Christ to a personal decision to follow him, as well as to place today's man „before the alternative of choosing between Christ and the prince of this world, between light and darkness, life and death, between sarx (flesh) and pneuma (spirit), between the wisdom of this world and the folly of the cross, between the Kingdom of God and the world, between civitas Dei (God's state) and civitas terrena (earthly state), between faith and unbelief. These antitheses belong to the essence of revelation and are inseparable from the Christian decision to believe" (Blachnicki 2005, p. 96). Eventually, Fr. Blachnicki appealed, which also shows the signs of the news, that "the focus of pastoral and catechetical efforts on the service of the faith is today a special canon, as in apostolic times" (Blachnicki 2005, p. 95).

Fr. Blachnicki took the thesis on the primacy of faith in catechesis from F.X. Arnold. He repeated after him that paying attention to faith above all does not diminish the role of the sacrament in the work of redemption, and even less does it represent some kind of dualism or parallelism, as if it were two separate salvific ways. These paths, on the other hand, must be seen in a close, dynamic relationship with each other. In this relationship, however, the main emphasis lies with the faith, for it creates the first and fundamental union with Christ. „In faith there is a real and inner union with Christ, faith gives participation in His life. Therefore, faith must be regarded as the salvific way (...) and as the most powerful 
supernatural reality, which makes union with Christ, who is salvation in persona (...). The primacy of faith in relation to the sacrament is expressed above all in the fact that the sacraments presuppose faith and all their effectiveness is conditioned by faith" (Blachnicki 2005, pp. 93-94: Blachnicki 2008). In this way, faith also has its priority in the salvific mediation or in the pastoral care. „This means that pastoral care must first and foremost be geared towards awakening and deepening the faith" (Blachnicki 2005, p. 95). In this context, Blachnicki argued, every pastor and catechist must be aware of this truth, as well as be personally involved in the life of faith, because only then will it be crucial in both the saving process and in life. It is also to educate so that there is indeed a conscious process of creating a new man, according to the Gospel. Therefore, he proposed the catechesis of the New Man's pedagogy to the Light-Life Movement and to the whole Church in Poland (Czupryński 2011, pp. 181-195).

Father Blachnicki devoted much of his texts about faith as the aim of catechesis in order to justify its personalistic character, the concept of which he also drew from Arnold. He extracted historical data, but above all he emphasized that faith is the act of the whole person who responds to God revealing himself and submits his whole life to Him. It presupposes the personal encounter of man with God in Christ, it is the man's response to God's call, affirmation of the whole life of God manifested as the highest value of life. "The object of faith is the personal God, acting in history for the salvation of man, and therefore it is the Christ, and it is Totus Christus living in the Most Holy Trinity, in the Church and in us" (Blachnicki 2005, p. 101). In pastoral care and catechesis, therefore, it would be necessary to continue to awaken and deepen the faith, and not being content with the fact that this problem, as Blachnicki writes, was dealt with once and for all in the systematic teaching of faith at school age (Blachnicki 2005, p. 103).

The personalistic description of the faith demands recognition of its community and ecclesiastical dimension. In this regard, Fr. Blachnicki referred to the thoughts of the French catechist A. Sironval (1961): ,the faith to which catechesis is to be brought up is not an individual faith, but a faith of the Church. Many Christians, even zealous Christians, live their Christian lives alongside the life of the Church, but not in the Church. Meanwhile, every Christian is a Church, because the Church is all Christ, head and body parts, and we are its parts. And that is why the life of the Church increases as long as the life of each part's faith increases" (Blachnicki 2006, p. 171). Thus, he reached for the principle of the ancient Church, which can be described as a communion of faith, according to which the Church has a divine origin. „As a community created by God's love for man, its members felt that this special relationship with Him had been established through an act of faith. They were convinced that Christ could not be professed outside the community" (Widok 2004, pp. 80-81). We can find a similar position in the teaching of Pope Benedict XVI, for whom the Church's missionary prophesy, since its beginnings, flows from the faith and the whole Church is involved in it (Benedykt XVI 2010, No. 92). The 
relationship of faith to the Church was not perceived by the Servant of God in the people's Church, a mass Church in which religious practices do not always derive from or lead to faith. Surely, on the basis of his own observations, he wrote that ministers try to induce the faithful to partake of the sacraments, often mistakenly assuming that they have faith and do not ask for it. However, as he claimed, this is a great weakness of this type of Church. For him, it was obvious that faith was to be authentic, characterized by a personal commitment to Christ and a world of supernatural values (Blachnicki 2005, p. 105). For this reason, he set before catechesis and catechists ,the task of awakening and educating in the coming generations of true, supernatural and personalistic faith. Undoubtedly, the future of Catholicism in individual environments depends on the future of Catholicism but only if catechesis can deliver on this task" (Blachnicki 2005, p. 107)

This is where the legitimate conclusion arises that in the Church in Poland, where parish catechesis has been abandoned and the catechesis of adults is not undertaken on a larger scale, the crisis of faith still exists and it deepens. Religious instruction in schools is unable, by its very nature, to awake and educate in the supernatural and personalistic faith, nor is it able to introduce those living in faith into the Church community. It is centred on the function of education and teaching, while education in faith calls for the function of initiation. This function is provided by parish catechesis. Liturgy fulfils to some extent the tasks of catechesis, but both liturgy and catechesis are needed for a full education in the faith. It is catechesis that introduces the liturgy, explains it and interprets the contents, actions and symbols contained in it in a vital way. Therefore, it would be necessary to call on Fr. Blachnicki to work intensively to restore awareness among the faithful about the need to repair natural educational environments and, above all, the family and the home catechumenate. If Fr. Blachnicki wrote, in the middle of the last century, about the need to create a new educational ministry (Blachnicki 2005, p. 266), then more so this cry is extremely relevant today, when many young people are now experiencing their lives outside the Church (Pawlina 2020; Zaręba 2014).

Translated by Elizabeth Ann Pilkington

\section{Bibliography}

Alberich E. (2003). Katecheza dzisiaj. Podręcznik katechetyki fundamentalnej. Warszawa: Wydawnictwo Salezjańskie.

Benedykt XVI (2010). Exhortation Verbum Domini. O słowie Bożym w życiu i misji Kościoła.

Rome. Polish edition: Pallotinum.

Blachnicki F. (2003). Sympatycy czy chrześcijanie. Katechumenat na dzisiejsza godzinę,

Kraków: Wydawnictwo Światło-Życie. Instytut ks. Franciszka Blachnickiego.

Blachnicki F. (2005). Pisma katechetyczne, I: Kerygmatyczna odnowa katechezy

(Zorientowanie w problematyce). Warszawa: Wydawnictwo Salezjańskie. 
Blachnicki F. (2006). Pisma katechetyczne, II: Katechetyka fundamentalna. Warszawa: Wydawnictwo Salezjańskie.

Blachnicki F. (2013). Pisma pastoralne. Teologia pastoralna ogólna, I/1: Wstęp do teologii pastoralnej. Teologiczne zasady duszpasterstwa. Warszawa: Wydawnictwo Salezjańskie. Blachnicki F. (2015). Teologia pastoralna ogólna, I/2: Eklezjologiczna dedukcja teologii pastoralnej. Warszawa: Wydawnictwo Salezjańskie.

Czaja A. (2004). Communio w eklezjologii Soboru Watykańskiego II i w dokumentach posoborowych. In: A. Czaja, M. Marczewski (eds.), Communio w chrześcijańskiej refleksji o Kościele. Lublin: Towarzystwo Naukowe Katolickiego Uniwersytetu Lubelskiego.

Czupryński W. (2011). Odnowa parafii i duszpasterstwa. Deuterokatechumenalna koncepcja chrześcijańskiej formacji w myśli i dziele ks. Franciszka Blachnickiego, Olsztyn: Biblioteka Wydziału Teologii Uniwersytetu Warmińsko-Mazurskiego.

Dyrektorium katechetyczne. (2020). Polish edition: Kielce, Wydawnictwo JEDNOŚĆ. Jan Paweł II. (1988). Apostolic letter Mulieris dignitatem, Polish edition: Wydawnictwo św. Stanisława B.M. Archidiecezji Krakowskiej. Wydawnictwo M.

Kulbacki P. (2018). Teolog liturgii i mistagog. „Atenuem Kapłańskie”. 170/1, 58-72.

Marczewski M. (200o). Posługa zbawcza Kościoła w ujęciu ks. Franciszka Blachnickiego. Lublin: Wydawnictwo Polihymnia.

Marczewski M. (2004). Kościół jest sakramentem wspólnoty (Ks. Franciszek Blachnicki 1921-1987). In: A. Czaja, M. Marczewski (eds.). Communio w chrześcijańskiej refleksji o Kościele. Lublin: Towarzystwo Naukowe Katolickiego Uniwersytetu Lubelskiego.

Marczewski M. (2018). Słowo - wiara - sakrament. U źródeł Kościoła-Osoby. „Ateneum Kapłańskie”. 170/ 2, 263-278.

Misiaszek K. (2018). Ks. Franciszek Blachnicki twórca nowego ujęcia katechetyki i katechezy. „Ateneum Kapłańskie”. 170/ 2, 249-254.

Misiaszek K. (2018a). Dziecięctwo Boże w wychowaniu według ks. Franciszka Blachnickiego. „Ateneum Kapłańskie”. 171/1, 65-79.

Misiaszek K. (2004), Kościół jako komunia w przekazie katechetycznym. In: A. Czaja, M. Marczewski, Communio w chrześcijańskiej refleksji o Kościele (445-461). Lublin:, Towarzystwo Naukowe Katolickiego Uniwersytetu Lubelskiego.

Murawski R. (2011). Wychowanie w wierze: co to jest? W: Wychowanie w wierze w kontekście przemian współczesności. Buchta R., Dziekoński S. (eds.). Katowice 2011: Księgarnia św. Jacka.

Pawlina K. (2020). Młodzież a chrześcijański system wartości. In: Młodzież i jej świat: Kościół i Ojczyzna. Sadowski R.F. (eds.). Warszawa: Towarzystwo Naukowe Franciszka Salezego. Sironval A. (1961). Puor une pedagogie catéchètique, Tournai.

Szymczak W. (2018). Promotor wspólnoty - zwiastun „wiosny Kościoła”, “Ateneum Kapłańskie”, t. 170, z. 1, 21-41.

Widok N. (2004). Charakterystyczne cechy patrystycznej eklezjologii communion. In: Communio w chrześcijańskiej refleksji o Kościele. Czaja A., Marczewski M. (eds.). Lublin: Towarzystwo Naukowe Katolickiego Uniwersytetu Lubelskiego. 
Zaręba S.H. (2014). Socjologiczna perspektywa ujęcia fenomenu polskiej młodzieży. W: Młodzież w przestrzeni wolności. W poszukiwaniu odpowiedzi na zmiany ustrojowe po roku 1989. Sadowski R.F. (eds.). Warszawa: Towarzystwo Naukowe Franciszka Salezego.

\section{KATECHEZA I WYCHOWANIE W FUNKCJI BUDOWANIA KOŚCIOŁA WEDŁUG KS. FRANCISZKA BLACHNICKIEGO. (W STULECIE URODZIN WIELKIEGO WYCHOWAWCY)}

Streszczenie: Dla ks. Franciszka Blachnickiego katecheza, jak również wychowanie pozostawały w ścisłym związku z Kościołem. Najwłaściwszym miejscem dla katechezy jako podstawowej wychowania chrześcijan (dorosłych, młodzieży i dzieci) jest Kościól, który jest zarazem podmiotem, celem i przedmiotem katechezy. Pojęcia Kościoła ks. Franciszek Blachnicki czerpał z opracowań autorów niemieckojęzycznych, a przede wszystkim z dokumentów Soboru Watykańskiego II. Kościół był dla niego pośrednikiem zbawienia, powszechnym sakramentem zbawienia, matką, świątynią Boga, a przede wszystkim zjednoczeniem ludu Bożego, wspólnotą w Chrystusie, wspólnotą wiary, nadziei i miłości.

Zadaniem katechezy i wychowania jest przede wszystkim wprowadzenie i doświadczenie Kościoła. Natura katechezy wynika z pojęcia Kościoła. Jeśli więc Kościół jest wspólnotą, to celem katechezy jest wprowadzenie wiernych, aby mogli w niej nie tylko uczestniczyć, ale przede wszystkim ją tworzyć i podejmować proces własnego wychowania. Ważne jest również to, że katecheza służy także procesowi inicjacji chrześcijańskiej, odkrywaniu Kościoła jako miejsca wypełniania się tajemnicy życia, zbawienia i uzdrowienia. Dlatego ks. Blachnicki kładł duży nacisk na związek liturgii z katechezą, gdyż w liturgii dokonuje się najpełniejszy proces wtajemniczenia.

Kolejnym zadaniem katechezy jest jej funkcja budzenia i rozwijania wiary. Wiara jest bowiem fundamentem Kościoła i podstawowym celem katechezy. Ma ona mieć charakter zarówno personalistyczny, jak i społeczny. Ksiądz Blachnicki twierdził, że katecheza wychowująca do wiary nie jest wiarą indywidualną, ale wiarą Kościoła. Wielu chrześcijan, nawet tych najbardziej gorliwych, przeżywa swoje chrześcijańskie życie obok życia Kościoła, ale nie w Kościele. Tymczasem każdy chrześcijanin jest Kościołem, ponieważ Kościół jest całym Chrystusem, Głową i członkami, a my jesteśmy jego członkami. Dlatego też życie Kościoła wzrasta o tyle, o ile wzrasta życie wiary każdego z jego członków, do czego potrzebny jest całościowo rozumiany proces chrześcijańskiego wychowania.

Słowa kluczowe: Ks. Franciszek Blachnicki, pojęcie Kościoła, katecheza, życie i doświadczenie Kościoła, wiara i katecheza, wychowanie. 
